\title{
Antibacterial Activities of the Extracts of Sponge-Associated Fungus Trichoderma longibrachiatum against Pathogenic Bacteria
}

Sri Sedjati ${ }^{13^{*}}$, Ambariyanto Ambariyanto ${ }^{1,2}$, Agus Trianto ${ }^{1,2}$, Endang Supriyantini ${ }^{1}$, Ali Ridlo1, Muhammad Syaifudien Bahry $^{2}$, Gita Wismayanti ${ }^{1}$, Ocky Karna Radjasa ${ }^{1}$, and Erin McCauley ${ }^{4}$

${ }^{1}$ Department of Marine Sciences, Faculty of Fisheries and Marine Sciences, Diponegoro University, Indonesia 50275 ${ }^{2}$ Integrated Laboratory, Diponegoro University, Jl. Prof. Soedarto, Tembalang, Semarang, Jawa Tengah, Indonesia 50275 ${ }^{3}$ Marine Science Techno Park Jl. Undip, Desa Teluk Awur, Tahunan, Jepara, Jawa Tengah 59427

${ }^{4}$ Department of Chemistry and Biochemistry, California State University Dominguez Hill, $1000 \mathrm{E}$. Victoria Street, Carson, California, USA 90747

Article history:

Received: 11 March 2020; Revised: 13 May 2020; Accepted: 22 June 2020

\begin{abstract}
This study aims to explore the antibacterial potential of a sponge-associated fungus Trichoderma longibrachiatum isolated from Ternate waters, North Maluku, Eastern Indonesia. Various culture media were used to stimulate the production of secondary metabolites in T. longibrachiatum. The isolate was cultured in various media for 6-9 days. Then, the antibacterial activities of the ethyl acetate extracts were assayed against pathogenic bacteria of Multi-Drug Resistant (MDR) strain (Pseudomonas aeruginosa, Staphylococcus aureus, Klebsiella pneumoniae, and Bacillus cereus). The results showed that all extracts had similar profiles on the thin layer chromatography. However, two of the most potent extracts were produced from the PCA and MEA media for 9 days. These extracts inhibited methicillinresistant S. aureus (MRSA) (12.48 $\mathrm{mm}$ and $12.27 \mathrm{~mm})$; B. cereus $(12.11 \mathrm{~mm}$ and $12.12 \mathrm{~mm})$; K. pneumoniae $(12.40 \mathrm{~mm}$ and $10.76 \mathrm{~mm})$; and P. aeruginosa $(11.59 \mathrm{~mm}$ and $8.69 \mathrm{~mm})$ at concentrations $500 \mu \mathrm{g} / \mathrm{disc}$. In conclusion, the fungus T. longibrachiatum that was cultured in PCA and MEA media had the potential to produce antibacterial compounds against MDR pathogens and both had similar compounds. Meanwhile, the ethyl acetate extracts from fungus cultured in the TPA and TA media were inactive against all tested bacteria.
\end{abstract}

Keywords: sponge-associated fungus, Trichoderma longibrachiatum, antibacterial activity, pathogen

\section{Introduction}

Indonesian waters are reservoir of various spongeassociated fungi, which are potential to produce antibacterial compounds. The ethyl acetate extract of Aspergillus nigerbiomass associated with Haliclona fascigera sponge from Mandeh Island waters (West Sumatra) has been reported to inhibit the growth of Staphylococcus aureus and Escherichia coli (Handayani et al., 2015). Aspergillus flavus, from the same waters, associated with the sponge Acanthrostrongylophora ingens also produced antibacterial compounds against Bacillus subtilis, $S$. epidermidis, Salmonella typhosa, and E. coli (Handayani \& Aminah, 2017). Aspergillus sydowii associated with Axinella sp. from Riung Island waters (East Nusa Tenggara) produced ethyl acetate extracts, that were active against $S$. aureus and E.coli "strain" Multi-Drug Resistant (MDR) bacteria (Widyaningsih et al., 2018). Furthermore, Triododerma saturnisporum associated with sponges from Pandang Island waters (North Sumatra) produced ethyl acetate extract with antibacterial activity against MDR S. enterica, Extended Spectrum Beta-Lactamase (ESBL) of $E$. coli and K. pneumoniae (Sibero et al., 2018a). Trichoderma reeseifrom the same waters, associated with Cinachyrella sp. produced antibacterial against of MRSA, MDR S. hemolyticus, S. enterica, and ESBL of $E$. coli (Sibero et al., 2018b). In our previous research, we isolated Pseudoalteromonas

${ }^{*}$ Corresponding author.

E-mail: sedjati69@gmail.com 
maricaloris, A. nomius, Eurotium rubrum, and Penicillium sp. from the sponge Reniera sp. All of the bacteria and fungi were active against MDR $S$. aureus and E. coli (Trianto et al., 2019b).

Thomas et al. (2010) and Nalini et al. (2018) reported various groups of secondary metabolites compounds of marine fungi with antibacterial activities. Other studies have successfully isolated antipathogenic bacterial compounds from marine fungi. Brevianmides from $A$. versicolor inhibited Bacille Calmette-Guerin (BCG) (Song et al., 2012); meanwhile scleroderolide, citrinin, and penicillosides $B$ from Penicillium sp. inhibited MRSA, wild type of $S$. aureus, vancomycin-resistant $E$. faecium, and $E$. coli $(\mathrm{Li}$ et al., 2019; Subramani et al., 2013; Murshid et al., 2016). Furthermore, spiculisporic acid $\mathrm{F}$ from $A$. candidus inhibited $P$. solanacearum and $S$. aureus (Wang et al., 2015); asperchondols B from Aspergillus sp. inhibited S. aureus and E. faecalis (Liu et al., 2016), and heterocornol from Pestalotiopsis heterocornis inhibited S. aureus and B. subtilis (Lei et al., 2017).

Several Trichodermasp. species have also been studied and have the potential to produce antibacterial compounds. Ethyl acetate extract of Trichodermasp. was reported to exhibit antibacterial activities against pathogens ( $E$. coli, $P$. aeruginosa, $S$. aureus, and $B$. cereus). The fungus isolated from the mangrove ecosystem (rhizosphere mangrove) has been shown to produce secondary metabolites that can be developed to overcome the crisis of bacterial resistance (Narendran \& Kathiresan, 2016; Basiriya et al., 2017). Similar results were also shown by Synytsya et al. (2017), the only difference is that the antibacterial compounds in the study were derived from petroleum ether and ethanol extracts. Data from several other researchers showed the potential of antibacterial compounds produced by Trichoderma sp., such as trichodermaquinone against MRSA (Khamthong et al., 2012), trichodins A \& B, and pyridoxatin against $S$. aureus and $S$. epidermidis $(\mathrm{Wu}$ et al., 2014). Li et al. (2019) stated that Trichoderma $\mathrm{sp}$. is a producer of various secondary metabolites with diverse biological activities. This fungus is commonly found and distributed throughout the world, spreading in many ecosystems, including the ocean.

Despite their promising bioactivities, not all spongeassociated fungi can be cultured. To overcome this problem, an appropriate solid media can be used for the adaptation phase of the fungus from its original environment to the condition in the laboratory. Solid media have been shown to increase the production of secondary metabolites or enzyme secretion from the fungus. On the other hand, cultivating a fungus in liquid media has been considered reducing the efficiency of metabolite production, although conventionally, this method has been widely applied to produce beneficial natural compounds (Barrios-González \& TarragóCastellanos, 2017). Fungal media must contain the sources of carbon (C), nitrogen $(\mathrm{N})$, macro-elements, and micro-elements. There are two general categories of culture media, natural and synthetic. Natural media is composed of natural ingredients, such as plants, seeds, wood/stems, and other natural materials (Basu et al., 2015), rice, grits, oatmeal, wheatgerm (Vandermolen et al., 2013), cassava, potato, taro (Wongjiratthiti \& Yottakot, 2017). The advantage of this natural media is the ease of preparation; although the chemical composition is not measurable.

Alternatively, the use of synthetic media allows the accurate measurement of chemical composition in the fungi extract. The only drawback of this method is its cost-prohibitive. This study therefore aims to explore the potential of sponge-associated fungus $T$. longibrachiatum as a producer of antibacterial compounds against the MDR pathogens. The isolated fungus was cultivated in various alternative media to stimulate the production of secondary metabolites.

\section{Material and Methods}

\subsection{Fungus Isolate}

The fungus was isolated from a sponge obtained from Falajava Beach, Ternate Island, North Maluku, Indonesia (coordinates 00 $47^{\prime} 09.12^{\prime \prime} \mathrm{N} ; 127^{\circ} 23^{\prime 2} 21.76^{\prime \prime}$ E) and was coded as TE-PF-03.1. Molecular identification of ITS rDNA sequences indicated the fungus as Trichoderma longibrachiatum (Trianto et al., 2020).

\subsection{Morphological Characterization of The Fungus}

Morphological characterization confirmed that the sample fungus was $T$. longibrachiatum. The isolate was cultured using Malt Extract Agar (MEA) (Merck) media for seven days at $27^{\circ} \mathrm{C}$ to observe its colony shape. Microscopic characteristics were determined based on slide culture method (Bath, 2017; Sibero et al., 2017) with 100-1000 times magnification.

\subsection{Pathogenic Bacteria}

The tested pathogenic bacteria were MDR strain, consisting of $P$. aeruginosa, $S$. aureus, K. pneumoniae, and $B$. cereus. These test bacteria were obtained from the laboratory of Diponegoro National Hospital (RSND) and collections belonging to the authors' peer group, the Integrated Laboratory of Diponegoro University, Semarang. 


\subsection{Preparation of Antibacterial Activity}

The preparation of antibacterial activity was initiated by antagonistic testing using the agar plug method (Trianto et al., 2017; Sibero et al., 2018a). The fungus was cultured in MEA for seven days at $27^{\circ} \mathrm{C}$. The mycelium was taken out approximately at the size of a $1-\mathrm{cm}$ diameter circle with a cork borer. The test bacteria of $P$. aeruginosa, $S$. aureus, K. pneumoniae, and $B$. cereus MDR strain were cultured using Mueller Hinton Agar (MHA) media. Preparation of test bacteria was conducted using a 24-hour-old bacterial suspension with a density equivalent to $1.5 \times 10^{8} \mathrm{CFU} /$ $\mathrm{ml}$ (REMEL McFarland Equivalence), which was inoculated with the swab method. The mycelium with a $1-\mathrm{cm}$ diameter circle was plugged to the test bacterial culture, and the Petri dish was closed and then incubated for $24-48 \mathrm{~h}$ at $37^{\circ} \mathrm{C}$. The antibacterial activity was indicated by the formation of inhibition zones around plug fungus.

\subsection{Cultivation of Fungus}

The fungus was subcultured using MEA media. The mycelium was taken out from the media using a circular loop needle with a 2-mm diameter and inoculated in new media. The media used were MEA as standard media and some modified media (solid, $20 \mathrm{~mL} /$ petri dish), the $\mathrm{pH}$ was near neutral (around $5.60-6.50$ ), with $50-60 \%$ salinity. The fungus, was incubated for $6,7,8$, and 9 days ( 24 hours in dark and static conditions) at $27^{\circ} \mathrm{C}$ as described by Hamad et al. (2014).

The modified media were prepared based on the methods of Wongjiratthiti \& Yottakot (2017) and Trianto et al. (2019a) with some modifications. Modified media used include: Fructose Fish-Infusion Agar (FFA), Glucose Fish-Infusion Agar (GFA), Tofu Pulp-Infusion Agar (TPA), Tempeh-Infusion Agar (TA), Cassava-Infusion Agar (CA), and Pepton CassavaInfusion Agar (PCA). The followings are steps of media preparation. The MEA was prepared by dissolving 48 $\mathrm{g}$ media in $1 \mathrm{~L}$ of sterile seawater $(30 \mathrm{~g}$ malt extract, $3 \mathrm{~g}$ peptone, $15 \mathrm{~g}$ agar) (Merck's protocol). The FFA was prepared by boiling $100 \mathrm{~g}$ of Indian mackerel (Rastrelliger sp.) in $1 \mathrm{~L}$ of sterile seawater for $30 \mathrm{~min}$. The boiled water was filtered, then the filtrate was added with $20 \mathrm{~g}$ fructose and $15 \mathrm{~g}$ agar (volume of the total solution on all media was $1 \mathrm{~L}$ in sterile seawater). The GFA was prepared as the FFA, but the fructose was replaced by glucose. The TPA was prepared by boiling $100 \mathrm{~g}$ tofu pulp/waste in $1 \mathrm{~L}$ of sterile seawater for $30 \mathrm{~min}$ and filtered, then the filtrate was added with $15 \mathrm{~g}$ agar. The TA was prepared by boiling $100 \mathrm{~g}$ of small pieces of tempeh in $1 \mathrm{~L}$ of sterile seawater for $30 \mathrm{~min}$ and was subsequently filtered. After that, the filtrate was added with $15 \mathrm{~g}$ agar. The CA was prepared by boiling $100 \mathrm{~g}$ of cassava for $30 \mathrm{~min}$ in $1 \mathrm{~L}$ of sterile and filtered seawater. After filtration, the filtrate was added with $15 \mathrm{~g}$ agar. The PCA was prepared as the $\mathrm{CA}$, but the filtrate was added with $3 \mathrm{~g}$ peptones and $15 \mathrm{~g}$ agar.

\subsection{Extraction and Profiling of Secondary Metabolites}

The culture media and the mycelia were macerated with methanol $(1: 1, \mathrm{v} / \mathrm{v})$ and concentrated with a rotary evaporator under vacuum at $35-40{ }^{\circ} \mathrm{C}$ until the remaining volume was $25 \%$. Then, the extract was partitioned using distilled water and ethyl acetate $(1: 1$, $\mathrm{v} / \mathrm{v})$. The ethyl acetate (EA) layer was concentrated using the rotary evaporator $\left(40^{\circ} \mathrm{C}\right)$ to provide the crude extract. Chemical profiling of the EA extract was conducted using thin-layer chromatography (TLC) on TLC plates (Merck-silica gel plate $60 \mathrm{~F}_{254}$ ). After development, the TLC was visualized with UV light $(254 / 366 \mathrm{~nm})$ and subsequently sprayed with reagent; $2 \%$ vanillin $-\mathrm{H}_{2} \mathrm{SO}_{4}, 0.25 \%$ ninhydrin in acetone, and $1 \%$ ferric (III) chloride in methanol (Harborne, 1973; Sen et al., 2012; Trianto et al., 2019a). The plates were then heated at $110^{\circ} \mathrm{C}$ for $2-3 \mathrm{~min}$.

\subsection{Antibacterial Activity}

Test bacteria were cultured using MHA media with the initial density equivalent to $1.5 \times 10^{8} \mathrm{CFU} / \mathrm{ml}$, and the bioassay was tested using 24-hour-old bacteria. The antibacterial bioassay was conducted by determining the diameter of the inhibition zone using disc diffusion based on Trianto et al. (2017). Inhibition zones were measured after a 24-hour incubation period at $37^{\circ} \mathrm{C}$. Extracts in methanol solvent were tested against pathogenic bacteria using discs (Oxoid, $6 \mathrm{~mm}$ diameter) with $500 \mu \mathrm{g} / \mathrm{disc}$ concentration. The positive control used was chloramphenicol (Oxoid, $30 \mu \mathrm{g} / \mathrm{disc}$ ).

\subsection{Proximate Analysis of Culture Media}

The proximate analysis of the culture media was conducted using the AOAC method (1990). The moisture content was measured by the oven drying gravimetric method. The determination of total ash content was carried out by the furnaces combustion gravimetric method. The protein content was measured by the Kjeldahl method, and the crude fat content was measured by solvent extraction (soxhletation) gravimetric method. The carbohydrate content was calculated by reducing $100 \%$ with the total of moisture, ash, lipid, and protein content. 


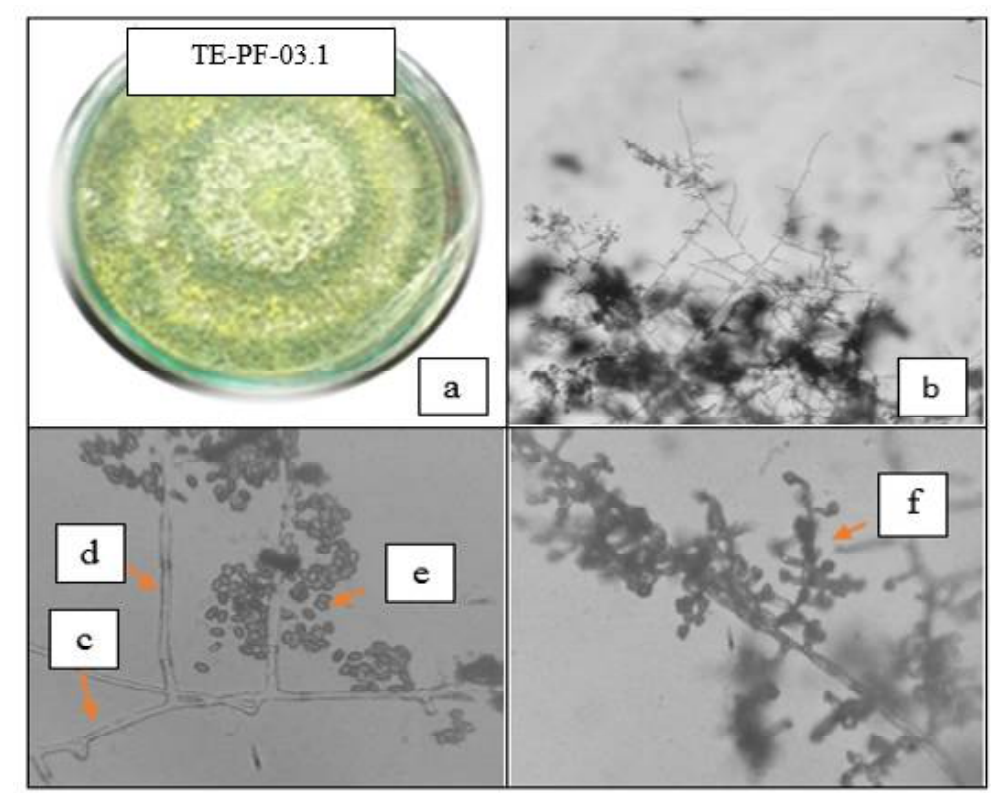

Figure 1. Microscopic morphology of fungus TE-PF-03.1 ((b) 100x, (c-f) 1000x magnification): (a) colony in MEA ( 7 days of incubation, $27^{\circ} \mathrm{C}$ ), (b) pustules, (c) partitioned hyphae, (d) conidiophores, (e) conidia, and (f) phialides

\section{Results and Discussion}

Fungus identification was determined as $T$. longibrachiatum based on morphological features and molecular tests (Trianto et al., 2020). Fungus $T$. longibrachiatum cultured in MHA media for seven days $\left(27^{\circ} \mathrm{C}\right)$ produced a yellowish-green colony (Figure 1a). The morphological details of the fungus can be seen under the microscope as in Figure 1b-f. The hyphae had a partition and conidiophores emerging from its hyphae's phialide. Elongated conidiophores had many short branches leading to phialides. These phialides' tip rounded to form conidia. These characteristics confirmed the morphology of $T$. longibrachiatum species as reported by others researchers. $T$. longibrachiatum markers, according to Richter et al. (1999) and Gams and Bissett (2002), typically have a conspicuous pigment, green-yellowish, at least when it was first isolated. The conidia have a green color, smooth surface, and ellipsoidal to obovoid shape. The main branches of conidiophores are long, producing short branches, ended with phialides, and the tips rounded to conidia. Similar observation was also reported by Samuels and Ismaiel (2012). The longibrachiatum clade of Trichoderma character shows that the phialides arise singly along the branches of the main axis and solitary phialide arises within a short distance of the main axis or its branches. The morphological identification of the fungus thus confirmed it as T. longibrachiatum.

The fungus $T$. longibrachiatum was cultured on modified media (FFA, GFA, TPA, TA, CA, and PCA) and MEA as the standard media. The fungus was able to produce ethyl acetate extracts (EE) in all media, as shown in Figure 2. The fungus produced the highest extract yields on day 6 in FFA, GFA, and CA; on day 7 in MEA and PCA; on day 8 in TA; and on day 9 in TPA. The highest secondary metabolites production occurred when the fungal growth phase was at the stationary phase. This result confirms the results of Gliseida et al. (2013), Arumugam et al. (2014), and Sibero et al. (2018a) that the production of secondary metabolites compound would increase when entering the stationary phase. In this research, the fungus entered the stationary phase by day 6-9.

Among all the of the tested media, fungus cultured in the GFA produced the highest EE yield, i.e., 27 $\mathrm{mg} / 20 \mathrm{~mL}$ media on day 6 . The fungus produced higher EE in all modified media than that in MEA during the stationary phase. The phase was not always reached on the same day in each media.

The abilities of fungus to grow, multiply, and secrete secondary metabolites are influenced by the nutrient content of their culture media. Macronutrients contained in the media are presented in Table 1. All media contained sources of $\mathrm{C}$ and $\mathrm{N}$, which were sufficient for fungal life during cultivation and could stimulate biosynthesis of secondary metabolites.

Indian mackerel contains $72.24 \%$ water content, $19.14 \%$ protein, $8.19 \%$ lipid, and ash $1.42 \%$ (fresh weight) (Sonavane et al., 2017). It contains macrominerals $(\mathrm{Na}, \mathrm{K}$, and $\mathrm{Ca}$ ), microminerals ( $\mathrm{Fe}$ and $\mathrm{Zn}$ ), and vitamin $\mathrm{B}_{12}$ (Nurilmala et al., 2015). 


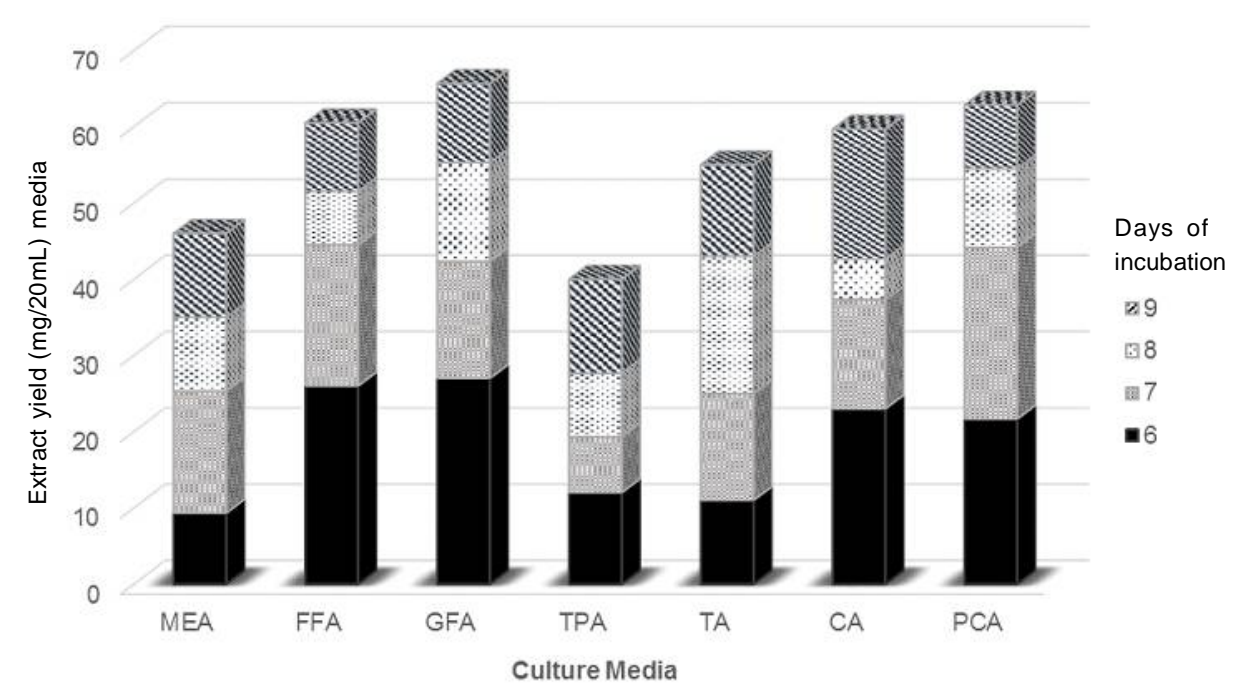

Note: $M E A=$ Malt Extract Agar; FFA $=$ Fructose Fish-Infusion Agar; GFA $=$ Glucose Fish-Infusion Agar; TPA = Tofu Pulp-Infusion Agar; TA = Tempeh-Infusion Agar; CA = Cassava-Infusion Agar; PCA = Pepton Cassava-Infusion Agar

Figure 2. Yield of ethyl acetate extracts of T. longibrachiatum on different days of incubation (6-9 days)

Table 1. Macronutrient composition of fungus culture media (\% wet basis)

\begin{tabular}{cccccc}
\hline Media & Water & Ash & Lipid & Protein & Carbohydrate \\
\hline MEA & 90.49 & 3.92 & 0.29 & 0.39 & 4.91 \\
FFA & 91.96 & 3.65 & 0.68 & 0.15 & 3.56 \\
GFA & 92.57 & 3.45 & 0.38 & 0.12 & 3.48 \\
CA & 93.72 & 4.01 & 0.77 & 0.08 & 1.42 \\
PCA & 93.86 & 3.55 & 0.45 & 0.17 & 1.97 \\
\hline
\end{tabular}

Note: MEA = Malt Extract Agar; FFA = Fructose Fish-Infusion Agar; GFA = Glucose Fish-Infusion Agar; TPA = Tofu Pulp-Infusion Agar; TA = Tempeh-Infusion Agar; $C A=$ Cassava-Infusion Agar; PCA $=$ Pepton CassavaInfusion Agar

Meanwhile, the fresh cassava contains water $60 \%$, starch $35 \%$, crude fiber $2.5 \%$, protein $1 \%$, lipid $0.5 \%$, and ash 1\% (Prabawati et al., 2011). Cassava has high mineral content, containing the macro elements i.e. $\mathrm{Na}, \mathrm{K}, \mathrm{Mg}, \mathrm{Ca}$, and $\mathrm{Cl}$, and the microminerals i.e. Mn, Zn, V (Danso et al., 2001) as well as vitamins B, and C (Depkes RI., 1995). Table 1 showed that all media contained high ash content, so it could be assumed that the needs of the mineral for fungal growth were fulfilled. Source of $C$ could be derived from carbohydrate, protein, and lipid, but $\mathrm{N}$ could only be obtained from protein. The production of biomass and secondary metabolite reaches a peak when the source of $\mathrm{N}$ is high, but $\mathrm{C}$ is low, so the $\mathrm{C} / \mathrm{N}$ ratio is very crucial (Lee et al., 2008; Dinarvand et al., 2013). Minerals and vitamins in the chemical reaction of fungi metabolism play a role an energy source or signal transduction, enzyme activity, heme-protein, cytochrome, and redox reaction (Walker \& White, 2005).

Compounds in EE from cultured fungus could be traced through the spot profile on the TLC chromatogram (Figure 3). The blue fluorescent spots when exposed to UV light indicates the presence of organic compounds with double bonds (diene/polyene or conjugation) (Mohammed, 2018). Compounds that react positively with vanillin reagents will generate certain colored spots (varying colors) characterizing the presence of carbonyl functional groups (e.g., ketones and aldehydes); such as phenolic, flavonoids, terpenoids, steroids, fatty acids/essential oils, or high molecular weight alcohol groups. Vanillin reagents are sensitive to steroids (Harborne, 1973; Jork et al., 1990). 


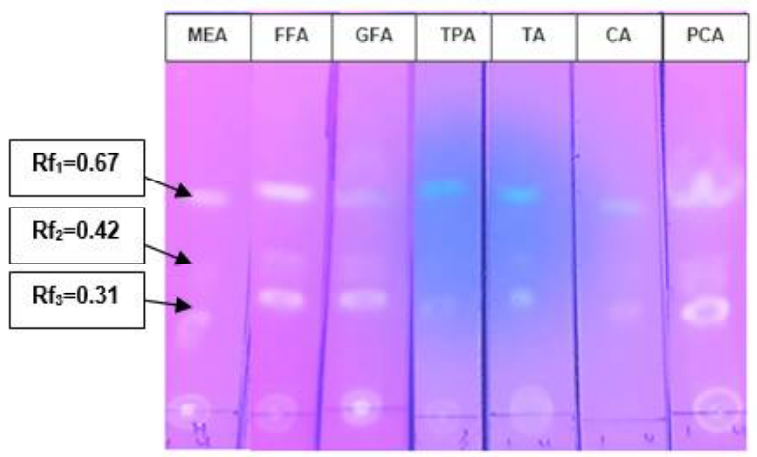

(a)

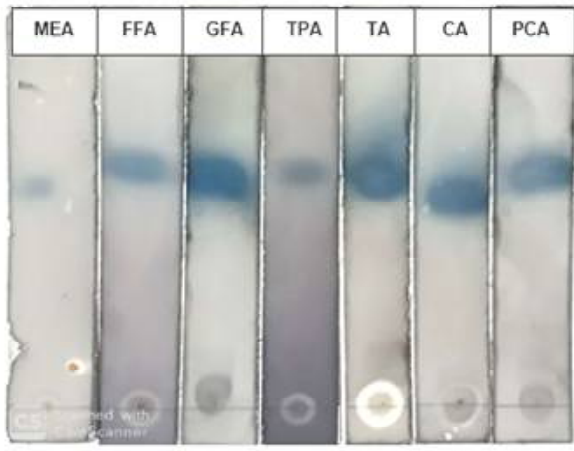

(b)

Note: $M E A=$ Malt Extract Agar; FFA $=$ Fructose Fish-Infusion Agar; GFA $=$ Glucose FishInfusion Agar; TPA = Tofu Pulp-Infusion Agar; TA = Tempeh-Infusion Agar; CA = CassavaInfusion Agar; PCA = Pepton Cassava-Infusion Agar

Figure 3. TLC profiles of ethyl acetate extracts of $T$. longibrachiatum cultivated in various media using nhexane: ethylacetate (4:1) as mobile phase and their chromatogram spot visualization (a) UV 365 $\mathrm{nm}$, (b) $2 \%$ vanillin- $\mathrm{H}_{2} \mathrm{SO}_{4}$

The fungus that cultured in MEA produced three spots $\left(\mathrm{Rf}_{1}=0.67 ; \mathrm{Rf}_{2}=0.42 ; \mathrm{Rf}_{3}=0.31\right)$, which are reactive to UV $365 \mathrm{~nm}$, but only $\mathrm{Rf}_{1}$ was reactive to $2 \%$ vanillin $-\mathrm{H}_{2} \mathrm{SO}_{4}$. Similar TLC patterns were also observed from the extracts of fungus grown in the other media. Visualization under UV $365 \mathrm{~nm}$ and $2 \%$ vanillin- $\mathrm{H}_{2} \mathrm{SO}_{4}$ indicated that the first spot $\left(\mathrm{Rf}_{1}\right)$ might contain conjugated compounds (e.g., diene, polyene or benzene ring) which possess a ketone or aldehyde group. This spot was relatively nonpolar since it interacts most strongly with its mobile phase. Two other spots $\left(\mathrm{Rf}_{2} \& \mathrm{Rf}_{3}\right)$ only positively absorbed UV $365 \mathrm{~nm}$, indicated that both spots contained conjugated compounds. All of the three spots were not of nitrogen (e.g., amines, peptides, or alkaloids) or phenolic (e.g., phenolic acids, polyphenols, flavonoids, lignans) compounds, since they were not reactive to ninhydrin and ferric chloride reagents (Harborne, 1973).

Some of the compounds contained in $T$. longibranchiatum extract have been researched. Extract of ethyl acetate from marine-derived fungus T. Iongibrachiatum from Jiaozhou Bay, Qingdao, China contained two structural series of sesquiterpenes and cyclodepsipeptides, both have antifungal activity (Du et al., 2020). Other studies reported that the extract of ethyl acetate of $T$. longibrachiatum associated with the sponge Haliclona sp. from Sulawesi contained vertinoid polyketides (Sperry et al., 1998). The vertinoids (also called sorbicillinoids) are hexaketide secondary metabolites in which the cyclization has taken place on the carboxylate terminus. Several of them have antibacterial activity, such as rezishanone A-D, sorbicillinol, 2,3-dihydrosorbicillin as well as sohirnones A \& C (Harned \& Volp, 2011). Sorbicillinoids are important hexaketide metabolites derived from fungi because it has a variety of bioactivities including antioxidant, cytotoxic, antiviral and antimicrobes.

Based on the TLC spot profiles, it was assumed that all EEs contained three compounds (Figure 3). In comparison to previous studies, the TLC profiles may indicate the presence of terpenoids (such as sesquiterpenes) and/or polyketides (such as sorbicillinoids).

In the antibacterial assay, it was found that all EEs formed inhibition zones, except EEs from TPA and TA media culture. The results of the antibacterial assay against four test bacteria are presented in Table 2. Extracts produced from PCA and MEA culture media (9 days of incubation) were the most potent. Extracts from PCA and MEA media inhibited the growth of the tested pathogenic bacteria: MRSA $(12.48 \mathrm{~mm}$ and $12.27 \mathrm{~mm}$ ), B.cereus (12.11 mm and $12.12 \mathrm{~mm}), K$. pneumoniae $(12.40 \mathrm{~mm}$ and $10.76 \mathrm{~mm}), P$. aeruginosa (11.59 $\mathrm{mm}$ and $8.69 \mathrm{~mm}$ ), respectively.

The EE of CA culture media was inactive against $P$. aeruginosa and $B$. subtilis, whereas those of FFA and GFA culture media were inactive only against $B$. subtilis. The fungus from all culture media contained similar compounds, but only MEA and PCA produced extracts with the highest antibacterial activities. It was suspected that the concentrations of the secondary metabolite were probably higher in both extracts than in the other investigated extracts so that they could inhibit the growth of the tested bacteria. 
Table 2. Inhibition zones of ethyl acetate extracts of $T$. longibrachiatum against pathogenic bacteria

\begin{tabular}{|c|c|c|c|c|}
\hline \multirow{2}{*}{$\begin{array}{l}\text { Day of incubation/ } \\
\text { Media }\end{array}$} & \multicolumn{4}{|c|}{ The diameter of inhibition zone (in $\mathrm{mm}$ excluding disc) } \\
\hline & K. pneumoniae & P. aeruginosa & MRSA & B. subtilis \\
\hline \multicolumn{5}{|c|}{ MEA } \\
\hline 6 days & $8.43 \pm 0.23$ & $9.63 \pm 1.11$ & $10.07 \pm 0.45$ & $7.88 \pm 0.01$ \\
\hline 7 days & $8.90 \pm 0.00$ & $9.63 \pm 0.00$ & $10.01 \pm 0.00$ & $7.89 \pm 0.00$ \\
\hline 8 days & $8.85 \pm 0.00$ & $9.68 \pm 0.00$ & $9.69 \pm 0.57$ & $8.02 \pm 0.30$ \\
\hline 9 days & $10.76 \pm 0.00$ & $8.69 \pm 1.01$ & $12.27 \pm 0.00$ & $12.12 \pm 0.00$ \\
\hline \multicolumn{5}{|c|}{ FFA } \\
\hline 6 days & $0.00 \pm 0.00$ & $0.00 \pm 0.00$ & $0.00 \pm 0.00$ & $0.00 \pm 0.00$ \\
\hline 7 days & $9.81 \pm 0.80$ & $10.73 \pm 0.12$ & $10.96 \pm 0.37$ & $0.00 \pm 0.00$ \\
\hline 8 days & $11.21 \pm 0.90$ & $10.91 \pm 0.06$ & $10.35 \pm 0.15$ & $0.00 \pm 0.00$ \\
\hline 9 days & $10.12 \pm 1.00$ & $8.61 \pm 0.05$ & $8.79 \pm 0.00$ & $0.00 \pm 0.00$ \\
\hline \multicolumn{5}{|c|}{ GFA } \\
\hline 6 days & $8.08 \pm 0.31$ & $0.00 \pm 0.00$ & $0.00 \pm 0.00$ & $0.00 \pm 0.00$ \\
\hline 7 days & $7.13 \pm 0.00$ & $7.90 \pm 0.00$ & $0.00 \pm 0.00$ & $0.00 \pm 0.00$ \\
\hline 8 days & $8.15 \pm 0.00$ & $8.33 \pm 0.00$ & $0.00 \pm 0.00$ & $0.00 \pm 0.00$ \\
\hline 9 days & $8.02 \pm 0.00$ & $7.34 \pm 0.10$ & $8.60 \pm 0.51$ & $0.00 \pm 0.00$ \\
\hline \multicolumn{5}{|c|}{ CA } \\
\hline 6 days & $0.00 \pm 0.00$ & $0.00 \pm 0.00$ & $0.00 \pm 0.00$ & $0.00 \pm 0.00$ \\
\hline 7 days & $0.00 \pm 0.00$ & $0.00 \pm 0.00$ & $0.00 \pm 0.00$ & $0.00 \pm 0.00$ \\
\hline 8 days & $8.85 \pm 0.20$ & $0.00 \pm 0.00$ & $8.95 \pm 0.48$ & $0.00 \pm 0.00$ \\
\hline 9 days & $0.00 \pm 0.00$ & $0.00 \pm 0.00$ & $0.00 \pm 0.00$ & $0.00 \pm 0.00$ \\
\hline \multicolumn{5}{|c|}{ PCA } \\
\hline 6 days & $0.00 \pm 0.00$ & $0.00 \pm 0.00$ & $0.00 \pm 0.00$ & $0.00 \pm 0.00$ \\
\hline 7 days & $0.00 \pm 0.00$ & $0.00 \pm 0.00$ & $0.00 \pm 0.00$ & $0.00 \pm 0.00$ \\
\hline 8 days & $0.00 \pm 0.00$ & $0.00 \pm 0.00$ & $0.00 \pm 0.00$ & $0.00 \pm 0.00$ \\
\hline 9 days & $12.40 \pm 0.00$ & $11.59 \pm 0.55$ & $12.48 \pm 0.00$ & $12.11 \pm 0.00$ \\
\hline $\begin{array}{c}\text { Chloramphenicol } \\
\text { (30 } \mu \mathrm{g} / \text { disc) }\end{array}$ & $29.7 \pm 1.32$ & $26.55 \pm 1.26$ & $31.37 \pm 2.05$ & $24.43 \pm 0.93$ \\
\hline
\end{tabular}

Note: Values are means $(n=3) \pm$ SD; MEA = Malt Extract Agar; FFA= Fructose Fish-Infusion Agar; GFA = Glucose FishInfusion Agar; TPA = Tofu Pulp-Infusion Agar; TA = Tempeh-Infusion Agar; CA = Cassava-Infusion Agar; PCA = Peptone Cassava-Infusion Agar

\section{Conclusion}

Sponge-associated fungus T. longibrachiatum from Falajava Beach, Ternate Island had the potential to produce antibacterial compounds against $P$. aeruginosa, S. aureus, K. pneumoniae, and B. cereus. The fungus $T$. longibrachiatum was successfully grown in various media (MEA, FFA, GFA, TPA, TA, CA, and
PCA). The fungus produced similar secondary metabolites, as indicated by both the number and characteristic spots on the TLC plate. PCA and MEA were two of the best culture media for the production of secondary metabolites that exhibited antibacterial activity against four pathogenic test bacteria with inhibition zone diameters ranging from 7.88-12.48 mm. 


\section{Acknowledgments}

This research is part of the final project of doctoral education program at the Department of Marine Sciences, Diponegoro University. Research funding was partially provided from by the Faculty of Fisheries and Marine Sciences, Diponegoro University, grant number: 35/UN 7.5.10/ PP/2019. This work was also supported by grants from USAID PEER Project \# 5215 (OKR), especially on the sample collection.

\section{References}

Arumugam, G. K., Srinivasan, S.K., Joshi, G., Gopal, D., \& Ramalingam, K. (2014). Production \& characterization of bioactive metabolites from piezotolerant deep sea fungus Nigrospora sp. in submerged fermentation. Journal of Applied Microbiology, 118, 99-111. doi: 10.1111/jam.12693.

AOAC. (1990). Official method of analysis (1 $5^{\text {th }}$ ed.). Association of official analytical chemist, Washington DC.

Barrios-González, J. \& Tarragó-Castellanos, M.R. (2017). Solid-state fermentation: special physiology of fungi. In: J.M. Mérillon, K. Ramawat K. (Eds.) Fungal metabolites. Reference Series in Phytochemistry (pp: 319-347). Springer, Cham. doi: 10.1007/978-3-31925001-4_6.

Basiriya, R., Anuswedha, A., \& Kalaiselvam, M. (2017). Antibacterial efficacy of crude extracts of Trichoderma spp. isolated from mangrove rhizosphere. International Research Journal of Pharmacy, 8(8), 70-73. doi: 10.7897/2230-8407.088147.

Basu, S., Bose, C., Ojha, N., Das, N., Das, J., Pal, M., \& Khurana, S. (2015). Evolution of bacterial \& fungal growth media. Bioinformation, 11(4), 182-184. doi: 10.6026/97320630011182.

Bhat, K. A. (2017). A new agar plate assisted slide culture technique to study mycoparasitism of Trichoderma sp. on Rhizoctonia solani and Fusarium oxysporium. International Journal of Current Microbiology and Applied Sciences, 6(8), 3176-3180. doi: 10.20546/ ijcmas.2017.608.378.

Danso, K.E., Serfor-Armah, Y., Nyarko, B.J.B., Osae, S., \& Osae, E.K. (2001). Determination of some mineral components of cassava (Manihot esculenta Crantz) using Instrumental Neutron Activation Analysis. Journal of Radioanalytical and Nuclear Chemistry, 250(1), 139-142. doi: 10.1023/A:1013236818791.

Depkes RI. (1995). Daftar komposisi zat gizi pangan Indonesia. Jakarta, Direktorat Jenderal Pembinaan Kesehatan Masyarakat.

Dinarvand, M., Rezaee, M., Masomian, M., Jazayeri, S.D., Zareian, M., Abbasi, S., \& Ariff, A.B. (2013). Effect of C/ $\mathrm{N}$ ratio and media optimization through Response Surface Methodology on simultaneous productions of intra- and extracellular inulinase and invertase from Aspergillus niger ATCC 20611. BioMed Research International. doi: 10.1155/2013/508968.
Du, F. Y., Ju, G. L., Xiao, L., Zhou, Y. M., \& Wu, X. (2020). Sesquiterpenes and cyclodepsipeptides from marine-derived fungus Trichoderma longibrachiatum and their antagonistic activities against soil-borne pathogens. Marine Drugs, 18(3), 165-175. doi: 10. 3390/md18030165.

Gams, W. \& Bissett, J. ( 2002). Morphology and identification of Trichoderma. In: C.P. Kubicek and G. E. Harman (eds.) Trichoderma and gliocladium Vol. 1. Basic biology, taxonomy, and genetics (pp 1-31). London, Taylor \& Francis Ltd.

Gliseida, B., Melgar, Z., Vanessa, F., De Assis, S., Coutinho, L., Fanti, S.C., \& Sette, L.D. (2013). Growth curves of filamentous fungi for utilization in biocatalytic reduction of cyclohexanones. Global Journals of Science Frontier Research Chemistry, 13(5), 13-19.

Hamad, H.O., Alma, M.H., Ismael, H.M., \& Eri, A. G. O. C. (2014). The effect of some sugars on the growth of Aspergillus niger. KSU Journal of Nature and Science 17(4), 7-11. doi: 10.18016/ksujns.28479.

Handayani, D., Ahdinur, R.F., \& Rustini, R. (2015). Antimicrobial activity of endophytic fungi from marine sponge Haliclona fascigera. Journal of Applied Pharmaceutical Science, 5(10), 154-56. doi: 10.7324/JAPS.2015.501027.

Handayani, D. \& Aminah, I. (2017). Antibacterial and cytotoxic activities of ethyl acetate extract of symbiotic fungi from West Sumatra marine sponge Acanthrongylophora ingens. Journal of Applied Pharmaceutical Science, 7(2), 237-40. doi: 10.7324/ JAPS.2017.70234.

Harborne, J.B. (1973). Phytochemical methods: A guide to modern techniques of plant analysis. New York, Chapman and Hall.

Harned, A.M. \& Volp, K.A. (2011). The sorbicillinoid family of natural products: Isolation, biosynthesis, and synthetic studies. Natural Product Reports, 28(11), 1775-1870. doi: 10.1039/c1np00039j.

Jork, H., Funk, W., Fisher, W., \& Wimmer, H. (1990). ThinLayer chromatography: reagents and detection methods, Vol.1: Physical and chemical detection methods. Germany, VCH Weinham.

Khamthong, N., Rukachaisirikul, V., Tadpetch, K., \& Kaewpet, M. (2012). Tetrahydroanthraquinone and xanthone derivatives from the marine-derived fungus Trichoderma aureoviride PSU-F95. Archives of Pharmacal Research, 35(3), 461-468. doi: 10.1007/ s12272-012-0309-2.

Lee, H. S., Song, H.H., Ahn, J.H., Shin, C.G., Lee, G.P., \& Lee, C. (2008). Statistical optimization of growth media for the production of the entomopathogenic and phytotoxic cyclic depsipeptide beauvericin from Fusarium oxysporum KFCC 11363P. Journal of Microbiology and Biotechnology, 18(1), 138-144.

Lei, H., Lin, X., Han, L., Ma, J., Dong, K., Wang, X., Zhong, J., Mu, Y., Liu, Y., \& Huang, X. (2017). Phytochemistry polyketide derivatives from a marine-spongeassociated fungus Pestalotiopsis heterocornis. 
Phytochemistry, 142, 51-59. doi: 10.1016/j.phy tochem.2017.06.009

Li, M. F., Li, G.H., \& Zhang, K.Q. (2019). Non-volatile metabolites from Trichoderma spp. Metabolites, 9(3), 2-24. doi: 10.3390/metabo9030058.

Liu, S., Dai, H., Konuklugil, B., Orfali, R. S., Lin, W., Kalscheuer, R., Liu, Z., \& Proksch, P. (2016). Phenolic bisabolanes from the sponge-derived fungus Aspergillus sp. Phytochemistry Letters, 18, 187-191. doi: 10.1016/j.phytol.2016.10.015.

Mohammed, A. M. (2018). UV-Visible spectrophotometric method and validation of organic compounds. European Journal of Engineering Research and Science, 3(3), 8-11. doi: 10.24018/ejers. 2018. 3.3.622.

Murshid, S. S. A., Badr, J.M., \& Youssef, D. T. A. (2016). Penicillosides $A$ and $B$ : New cerebrosides from the marine-derived fungus Penicillium Species. Revista Brasileira de Farmacognosia, 26(1), 29-33. doi: 10.1016/j.bjp.2015.09.007.

Nalini, S., Richard, D.S., Riyaz, S. U. M., Kavitha, G., \& Inbakan, D. (2018). Antibacterial macro molecules from marine organisms. International Journal of Biological Macromolecules, 115, 696-710. doi: 10.1016/j.ijbiomac.2018.04.110.

Narendran, R., \& Kathiresan, K. (2016). Antimicrobial activity of crude extracts from mangrove-derived Trichoderma species against human and fish pathogens. Biocatalysis and Agricultural Biotechnology, 6,189-194. doi: 10.1016/j.bcab. 2016. 03.003 .

Nurilmala, M., Nurjanah, N., Febriyansyah, R., \& Hidayat, T. (2015). Perubahan kandungan vitamin dan mineral ikan kembung lelaki akibat proses penggorengan. Depik, 4(2), 115-122. doi: 10.13170/depik.4.2.2688.

Richter, S., Cormican, M.G., Pfaller, M.A., Lee, C.K., Gingrich, R., Rinaldi, M.G., \& Sutton, D.A. (1999). Fatal disseminated Trichoderma longibrachiatum infection in an adult bone marrow transplant patient: species identification and review of the literature. Journal of Clinical Microbiology, 37(4), 1154-1160.

Samuels, G. J., \& Ismaiel, A. (2012). The longibrachiatum clade of Trichoderma: A revision with new species. Fungal Diversity, 55, 77-108. doi: 10.1007/s13225012-0152-2.

Sen, S., Sarkar, S., Kundu, P., \& Laskar, S. (2012). Separation of amino acids based on thin-layer chromatography by a novel quinazoline based antimicrobial agent. American Journal of Analytical Chemistry, 3(9), 669-674. doi: 10.4236/ajac. 2012.39088.

Sibero, M. T., Triningsih, D.W., Radjasa, O.K., Sabdono, A., \& Trianto, A. (2017). Evaluation of antimicrobial activity and identification of yellow pigmented marine sponge-associated fungi from Teluk Awur, Jepara, Central Java. Indonesian Journal of Biotechnology, 21(1), 1-11. doi: 10.22146/ijbiotech.26058.

Sibero, M.T., Triningsih, D.W., Radjasa, O.K., Sabdono, A., Trianto, A., Priyani, N., \& Prastyo, A. (2018a).
Antimicrobial activity of sponge-associated fungi from Pandang Island, North Sumatera against clinical pathogenic microorganisms. Asian Journal of Microbiology, Biotechnology \& Environmental Sciences Sc., 20(1), 142-149.

Sibero, M.T., Radjasa, O.K., Sabdono, A., Trianto, A., Triningsih, D.W., \& Hutagaol, I.D. (2018b). Antibacterial activity of Indonesian sponge-associated fungi against clinical pathogenic multidrug resistant bacteria. Journal of Applied Pharmaceutical Science, 8(2), 088-094. doi: 10.7324/JAPS.2018.8214.

Sonavane, A. E., Koli, J.M., Patange, S.B., Naik, S.D., \& Mohite, A.S. (2017). Proximate composition and fatty acid profiling of Indian mackerel (Rastrelliger kanagurta) off Ratnagiri, West Coast of India. International Journal of Pure \& Applied Bioscience, 5(4), 920-924. doi: 10.18782/2320-7051.5438

Song, F., Liu, X., Guo, H., Ren, B., Chen, C., Piggot, A.M., Yu, K., Gao, H., Wang, Q., Liu, M., Liu, X., Dai, H., Zhang, L., \& Capon, R.J. (2012). Brevianamides with antitubercular potential from a marine-derived isolate of Aspergillus versicolor. Organic Letters, 14(18), 4770-4773.

Sperry, S., Samuels, G. J., \& Crews, P. (1998). Vertinoid polyketides from the saltwater culture of the fungus Trichoderma longibrachiatum separated from a Haliclona marine sponge. Journal of Organic Chemistry, 63(26), 10011-10014. doi: 10.1021/jo98 08122.

Subramani, R., Kumar, R., Prasad, P., \& Aalbersberg, W. (2013). Cytotoxic \& antibacterial substances against Multi-Drug Resistant pathogens from marine sponge symbiont: Citrinin, a secondary metabolite of Penicillium sp. Asian Pacific Journal of Tropical Biomedicine, 3(4), 291-96.

Synytsya, A., Monkai, J., Bleha, R., Macurkova, A., Rumi, T., Ahn, J., \& Chukeatirote, E. (2017). Antimicrobial activity of crude extracts prepared from fungal Mycelia. Asian Pacific Journal of Tropical Biomedicine, 7(3), 257-261. doi: 10.1016/j.apjtb.2016.12.011

Thomas, T. R. A., Kavlekar, D.P., \& Bharathi, P.A.L. (2010). Marine drugs from sponge-microbe association-a review. Marine Drugs, 8(4), 1417-1468. doi: 10.3390/ md8041417.

Trianto, A., Widyaningsih, S., Radjasa, O.K., \& Pribadi, R. (2017). Symbiotic fungus of marine sponge Axinella sp. producing antibacterial agent. IOP Conference. Series: Earth and Environmental Science, 55: 012005. doi: 10.1088/1755-1315/55/1/012005.

Trianto, A., Sabdono, A., Radjasa, O.K., Pramesti, R., Putrajaya, N.T.S.,Bahry, M.S., Triningsih, D.W., Sulistiowati, S., \& Afriyanto, R. (2019a). Optimization production of antifungal substance from a spongeassociated Trichoderma harzianum cultivated in the tofu dregs and rice bran. Research Journal of Biotechnology, 14(10), 68-73.

Trianto, A., Nirwani, Susanti, O., Maesaroh, D., \& Radjasa, O. K. (2019b). The bioactivity of bacterium and fungi living associate with the sponge Reniera sp. against 
Multidrug-Resistant Staphylococcus aureus and Escherichia coli. Biodiversitas. 20(8), 2302-2307.

Trianto, A., Sedjati, S., Radjasa, O.K., Sabdono, A.,Muchlisin, S.I., Radjasa, S.K., Afriyanto, R., Bahri, M.S., Crews, P., \& McCauley, E. (2020). Exploration of the sponge-associated fungi form Ternate water, Indonesia. INPRESS.

Vandermolen, K. M., Raja. H.A., El-elimat, T., \& Oberlies, N.H. (2013). Evaluation of culture media for the production of secondary metabolites in a natural products screening program, $A M B$ Express, 3, 1-7.

Walker, G. M., \& White, N.A. (2005). Introduction to fungal physiology. In K. Kavanagh (Ed) Fungi: biology and applications (pp: 1-58). John Wiley \& Sons.

Wang, R., Kai, Z., Xiang, G., Li, M., \& Xiao, F. (2015). Spiculisporic acid analogues of the marine-derived fungus, Aspergillus candidus strain HDf2, and their antibacterial activity. Antonie van Leeuwenhoek, 108, 215-219. doi: 10.1007/s10482-015-0462-y.

Widyaningsih, S., Trianto, A., Radjasa, O.K., \& Wittriansyah, K. (2018). Antibacterial activity symbiotic fungi of marine sponge Axinella sp., Aspergillus sydowii on four growth media, IOP Conf. Series: Earth and Environmental Science, 116, 12084.

Wongjiratthiti, A. \& Yottakot, S. (2017). Utilisation of local crops as alternative media for fungal growth. Pertanika Pertanika, Journal of Tropical Agricultural Science, 40(2), 295-304.

Wu, B., Oesker, V., Wiese, J., Schmaljohann, R., \& Imhoff, J.F. (2014). Two new antibiotic pyridones produced by a marine fungus, Trichoderma sp. strain MF106. Marine Drugs,12(3), 1208-1219. doi: 10.3390/ md12031208. 